\title{
Digital Effect on University Decision: Perceptions of Teacher Candidates on Virtual Student Forums
}

\author{
Ibrahim Cankaya ${ }^{1}$, Engin Oztürk ${ }^{2}$, Enes Tepe ${ }^{3}$ \\ ${ }^{1}$ Usak University, Education Faculty, Usak, Turkey \\ ${ }^{2}$ Akdeniz University, Education Sciences Institute, Antalya, Turkey \\ ${ }^{3}$ Usak University, Social Sciences Institute, Usak, Turkey \\ Correspondence: Ibrahim Cankaya, Usak University, Education Faculty, Usak, Turkey
}

Received: November 26, 2015 Accepted: December 4, 2015 Online Published: December 22, 2015

doi:10.11114/jets.v4i3.1216 URL: http://dx.doi.org/10.11114/jets.v4i3.1216

\begin{abstract}
The objective of this study is to determine how much candidate teachers have utilized internet forums while deciding their university to study. This is a study in survey model. The population of the study consists of freshmen students studying at Usak University's Faculty of Education in 2014-2015 academic year (400 students). The scale has been distributed to the entire population, while 267 of them have been returned and 251 of them have been evaluated. "Virtual Forum Utilization during University Decision Period" scale has been developed by the researchers. The initial scale consisting of 14 items has been applied to 150 students and two items with low factor load have been dismissed. The renewed 12 item scale has been re-applied to the students. Cronbach-Alpha internal consistency coefficient of the scale has been calculated as .825 . Validity of the scale has been tested by exploratory and confirmatory factor analyses and $\mathrm{KMO}$ value of the scale has been calculated as .811. According to the confirmatory factor analysis, the scale consists of seven items and its fit index value has proved to be acceptable. $94 \%$ of the candidate teachers have memberships at student forums, while $89 \%$ of them get online at these forums several times a day. $42 \%$ of the teacher candidates utilize these forums to follow current affairs. Candidate teachers have reported that they had frequently visited student forums while they were about to decide their university to study. Independent groups $t$ test has yielded that there is no significant difference between the forum utilization levels of female and male candidate teachers. One way variance analysis has shown that candidate teachers at social sciences teaching department utilize student forums more than other departments.
\end{abstract}

Keywords: digital effect, virtual student forums, candidate teachers, university decision

\section{Introduction}

Alternative learning activities such as e-learning, e-supervision, e-mentoring, and e-counseling have become parts of education with the increasing use of digital equipment. Integration of digital equipment and digital platforms into education has redefined the borders of school. Utilization of digital technologies in education makes education more accessible. Effect of digital revolution could be seen in various fields such as education programs, evaluation, and career planning (İşcioğlu, 2012). This process not only strengthens an individual's learning efforts, but also accelerates individual-technology interaction and increases the role of technology in formal and informal education. Increasing popularity of the social networks is also causing people to spend more time in social networks, which affects individual lifestyles as well as yielding to new socialization methods (Göker, Demir and Doğan, 2010).

One new organizational type brought by digital tools is virtual societies. These societies exist with their construct properties, and merely show any physical properties (Fukuyama, 2013). One major type of these societies is virtual forums. Users may share their personal information, visit other users' profiles, publish, share or label multimedia content and access other users' content (Gürsakal, 2009).

There are various researches about the effects of forums on international trade, banking, marketing, media and public opinion. However these researches are very limited when it comes to frequency and purpose of digital media utilization about public opinion about schools, education marketing, student mobility, profession decision, and counseling and especially in higher education decision. Therefore it is important to identify the frequency and purpose of social media 
utilization in higher education and decision making for future profession. Hence, the objective of this study is to reveal how candidate teachers who are still studying in faculty of education have utilized virtual forums during their decision making period for their universities.

\section{Method}

\subsection{Model of the Study}

This study which aims to reveal how candidate teachers who are still studying in faculty of education have utilized virtual forums during their decision making period for their universities has been conducted in descriptive survey model. Survey models are used to describe the past or present condition of an event as is, without any effort to change or influence it (Karasar, 2009).

\subsection{Study Group}

The population of the study consists of 400 candidate teachers studying their freshman years during 2014-2015 spring semesters at Usak University's Faculty of Education. No sampling has been chosen and the scale has been distributed to each of the 400 students, while 251 returned has been evaluated.

\subsection{Data Collection Tool}

A 7-item scale developed by the researchers has been utilized to reveal how frequently the candidate teachers have visited forums and how it affected their university decision. All items in the scale are positive and the scale is uni-dimensional. The evaluation of scale points is as following: (1.00-1.80: never, 1.81-2.60: seldom, 2.61-3.40: sometimes, 3.41-4.20: usually, 4.21-5.00: always).

\subsection{Reliability and Validity of the Scale}

Reliability of the scale has been assured by test-retest reliability, two half tests reliability and Cronbach-Alpha internal validity coefficient. After formation of the 14-item pool of the scale, this preliminary scale has been applied to 150 candidate teachers and two items have been dismissed after this step, resulting in a 12 -item scale. The scale has been re-applied to all candidate teachers. The scale is a 5-scale Likert scale. It is a uni-dimensional scale consisting of positive sentences. Two half tests reliability analysis has revealed that there is positive and significant correlation between the scale items $(\mathrm{r}=.63, \mathrm{p}<.001)$. Cronbach Alpha coefficient of the scale has been calculated as (.825). These findings show that the scale is reliable. Content validity has been evaluated by expert review, while construct validity has been evaluated by exploratory and confirmatory factor analyses. Five items that decrease the validity of the scale according to exploratory factor analysis have been dismissed. Therefore final scale has been evaluated with seven items and uni-dimensionally (Table 1).

Table 1. Exploratory factor analysis

\begin{tabular}{|c|c|c|c|c|}
\hline \multirow{2}{*}{$\begin{array}{c}\text { Kaiser-Meyer-Olkin } \\
\text {,811 }\end{array}$} & \multirow{2}{*}{$\begin{array}{c}\text { Bartlett's Test } \\
\text {,000 }\end{array}$} & \multirow{2}{*}{$\begin{array}{c}\text { Percent of } \\
\text { Variance } \\
, 487 \\
, 514 \\
, 458 \\
, 556 \\
, 352 \\
, 467 \\
, 572\end{array}$} & \multicolumn{2}{|c|}{$\begin{array}{l}\text { Cumulative } \\
\text { Percent }\end{array}$} \\
\hline & & & 50,647 & 50,647 \\
\hline
\end{tabular}

Barlet test $(\mathrm{KMO}=.811)$ of the scale (.000) is significant. Total variance explanation of scale items is at $50 \%$. Confirmatory factor analysis has confirmed that the scale consists of seven items and is unidimensional (Figure 1). 


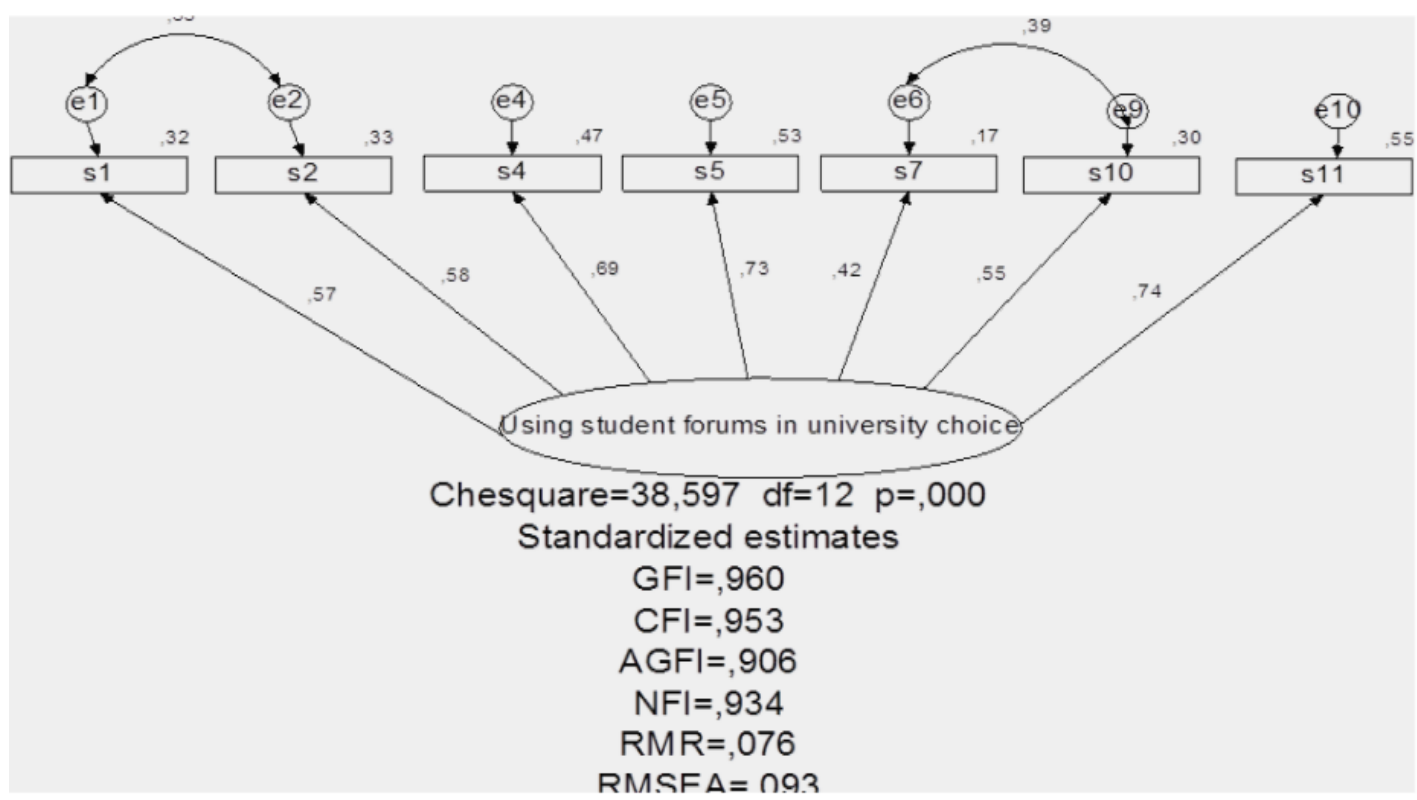

Figure 1. Comfirmatory factor analysis

Fit index of the scale $(\mathrm{GFI}=.860, \mathrm{CFI}=.910, \mathrm{NFI}=.866, \mathrm{CMIN} / \mathrm{DF}=2.67, \mathrm{RMSEA}=.82)$ has proved to be acceptable (Near and Gursoy, 2008).

\section{Findings}

This part shows branches of the candidate teachers and the findings about their opinions about visiting virtual student forums during their university decision period.

Table 2. Branches of the attending candidate teachers

$\begin{array}{ccc}\text { Department } & \text { Frequency } & \text { Percent } \\ \text { Science Teaching } & 87 & 33,5 \\ \text { Social Sciences Teaching } & 39 & 15,5 \\ \text { Turkish Teaching } & 92 & 36,7 \\ \text { Psychological Counseling and Guidance } & 36 & 14,3 \\ \text { Total } & 251 & 100\end{array}$

Of the 251 candidate teachers attending this study, 33.5\% (87) were studying at science teaching department, while $15.5 \%$ (39) were in social sciences teaching, $36.7 \%$ (92) were in turkish teaching, and $14.3 \%$ (36) were in psychological counseling and guidance departments.

Table 3. Forum membership of the teacher candidates to virtual student forums

$\begin{array}{cc}\text { Membership Status } & \text { Percent } \\ \text { Member } & 94 \\ \text { Non-member } & 6 \\ \text { Total } & 100\end{array}$

As seen at table three $94 \%$ of the candidate teachers have memberships in student forums, while $6 \%$ of them have no membership in any of them, showing that the vast majority of the students have at least one membership to a forum.

Table 4. Purpose of visiting virtual student forums

$\begin{array}{cc}\text { Purpose of Visit } & \text { Percent } \\ \text { Find new friends } & 0,4 \\ \text { Game playing } & 4,4 \\ \text { Chat } & 4,0 \\ \text { Following friends } & 12,7 \\ \text { Updating profile } & 2,8 \\ \text { Spending time } & 33,9 \\ \text { Following the current affairs } & 41,8 \\ \text { Total } & 100\end{array}$

Table four shows that $41.8 \%$ of the students use the forums primarily to follow the current affairs, while $33.9 \%$ use them to spend time, $12.7 \%$ to follow friends, $4.4 \%$ to play games, $4 \%$ to chat, $2.8 \%$ to update their profiles, and $0.4 \%$ to find new friends. Candidate teachers tend to follow professional developments, problems and suggestions by using student forums. 
Table 5. Level of student forums utilization during university decision period

\begin{tabular}{cccc}
\hline Minimum & Maximum & Mean & Standard Deviation \\
1 & 5 & 3,96 &, 853 \\
\hline
\end{tabular}

Table five shows that the answer given about forum utilization during university decision period is at Usually level.

Table 6. Candidate teachers' frequency of virtual forum visits

\begin{tabular}{cc}
\hline Student Forum Utilization Frequency & Percent \\
Several times a day & 88,9 \\
Once a day & 11,1 \\
Total & 100 \\
\hline
\end{tabular}

Table six shows that $88.9 \%$ of the candidate teachers in sampling group use student forums several times a day, while $11.1 \%$ of them visit daily. High frequency of visits shows that forums have an important place in learning and interaction process of higher education students.

In order to see whether there is significant difference of forum utilization with respect to gender, t-test analysis has been conducted, and it has been seen that there is no significant difference. The conducted t-test is given at table 7 .

Table 7. Evaluation of forum utilization with respect to gender

\begin{tabular}{ccccc}
\hline Gender & Number & Mean & Standard Deviation & P \\
Female & 179 & 3,52 &, 850 &, 771 \\
Male & 72 & 3,49 &, 869 & \\
\hline
\end{tabular}

According to the answers given by the candidate teachers, there is no significant difference with respect to gender in forum utilization $(\mathrm{p}>0.05)$.

Table 8. ANOVA test on visiting virtual student forums

\begin{tabular}{|c|c|c|c|c|c|c|}
\hline Department & Number & Mean & $\begin{array}{c}\text { Standard } \\
\text { Deviation }\end{array}$ & $\mathrm{F}$ & $\mathrm{P}$ & Difference \\
\hline Science Teaching & 84 & 3,55 &, 95 & & & sciences \\
\hline Social Sciences Teaching & 39 & 3,99 & 86 & & & students > sciences teaching, \\
\hline Turkish Teaching & 92 & 3,55 & 11 & 3,03 & ,03 & turkish teaching and guidance \\
\hline Guidance \& Counseling & 36 & 3,31 & 87 & & & \& counseling teaching students \\
\hline Total & 251 & & 82 & & & \\
\hline
\end{tabular}

Table eight shows the mean points and standard deviations of forum utilization for university decision of science, social sciences, Turkish and psychological counseling and guidance candidate teachers. Variance analysis applied to find out forum utilization level with respect to department variable has yielded significantly different mean values between performance evaluation points from different departments $(\mathrm{f}=3.03, \mathrm{p}<.05)$. The results show that social sciences candidate teachers utilize forums more than others. It could be stated that students studying in social fields use student forums as socializing tools.

\section{Conclusions}

This study has revealed that $94 \%$ of the students have memberships to at least one forum. Another study by Tanriverdi and Sağır (2014) has revealed that as much as $83.5 \%$ of high school students have memberships in social media. Therefore it could be stated that having memberships in social networks and following current affairs as well as communicating via social networks is a rising trend. According to Mazman (2009), students use virtual forums for information exchange, asking questions about deciding on professions, and resource exchange. According to Capogna (2010), virtual forums are commonly used by students for professional information acquiring and foreign language development purposes. A research by Toğay et.al (2015) has revealed that virtual forums in social media is the most frequently utilized tool of vocational school students in university decision, acquiring information, and lifelong learning.

About $89 \%$ of the candidate teachers have stated that they get online at forums several times a day. This shows that social media is an important interaction tool for candidate teachers. About $42 \%$ of the candidate teachers have stated that they use virtual forums to follow professional developments. This finding is in accordance with TUIK (2015) report. This report states that $78.8 \%$ of the internet users have utilized internet to get online in social networks, while $74.2 \%$ have used to read news, $67.2 \%$ to search information about goods and services, and $58.7 \%$ to download games, music, movies or visual materials, and $53.9 \%$ for email exchange in the first quarter of 2014. This shows that digital tools are increasingly being utilized for teaching and learning activities, especially by students, which proves the importance of designing teaching programs emphasizing on individual abilities and interests.

The world is in a time period in which virtual communication tools have affected teaching processes by "student forums" and communication between individuals by "getting online" after digital revolution. These developments make school and teachers impossible to stay as the only sources of information for majority of students. The number of alternative 
sources of information, virtual learning and teaching platforms are in increase in number. The notion of "learner" is being more widely used than the notion of "student" (Fukuyama, 2013). The sole role as information receivers for learners is obsolete anymore. Instead, individuals are now expected to query, reach, and interpret any information (Söylemez, 2013; Koçak, 2012). Therefore candidate teachers should be provided with project based social media literacy and virtual forum administration classes.

\section{References}

Capogna, S. (2010). Learning and Social Networks New Forms of Sociability. Retrieved from http://papers.ssrn.com/sol3/papers.cfm?abstract_id=1692082

Fukuyama, F. (2013). Big Decay. İstanbul: Profil Publication.

Göker, G., Demir, M., \& Doğan, A. (2010). Socialization and Sharing in The Network Society. E- Journal of New World Sciences Academy Humanities, 5(2), 183-206.

Gürsakal, N. (2009). Social Network Analysis. Bursa: Dora Publication.

İşcioğlu, A. (2012). University Students' Perceptions Towards Social Sharing Sites. (Unpublished Master's Thesis). Necmettin Erbakan University Education Sciences Institute, Konya.

Karasar, N. (2009). Research Method. Ankara: Nobel Publication.

Koçak, N. G. (2012). Social Media Usage Behaviour of Individuals. (Unpublished Ph D Thesis). Anadolu University Social Sciences Institute, Eskişehir.

Mazman, S. G. (2009). The Process of Adoption And Use in The Educational Context of Social Networks. (Unpublished Mater's Thesis). Hacettepe University Science and Technology Institute, Ankara.

Neal J. D., \& Gursoy, D. (2008). A Multifaceted Analysis of Tourism Satisfaction. Joutrnal of Travel Research, 47(1),53-62. http://dx.doi.org/10.1177/0047287507312434

Söylemez, N. H. (2013). The Research on Evaluation of Social Skills Level According To Teachers' Social Networking Use Conditions. (Unpublished Mater's Thesis). Dicle University Education Sciences Institute, Diyarbakır.

Tanrıverdi, H., \& Sağır, S. (2014). Effect on Student Achievement of Social Networking Adoption Levels of High School Students. Journal of Adlyaman University Social Sciences Institute, 7(18),776-787.

Toğay, A., Akdur, T. E., Yetişken, İ. C., \& Bilici, A. (2015). Use of Social Networking in Education Process. Retrieved from http://ab.org.tr/ab13/bildiri/302.pdf

Turkish Statistical Institute. (2015). Reports. Retrieved from http://www.tuik.gov.tr

\section{Appendix}

Scale of virtual forum utilization during university decision period

\begin{tabular}{|c|c|c|c|c|c|}
\hline & $\stackrel{\dot{d}}{\grave{z}} \Xi$ & $\stackrel{\Xi}{\frac{\tilde{Z}}{d}}$ & $\stackrel{\mathscr{E}}{\mathscr{E}}$ & 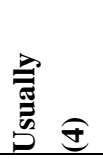 & $\sum_{n}^{\infty}$ \\
\hline \multicolumn{6}{|l|}{$\begin{array}{l}\text { I follow posts on social media student forums about preferences for my university } \\
\text { decision. }\end{array}$} \\
\hline \multicolumn{6}{|l|}{ I visit student forums for my university decision } \\
\hline \multicolumn{6}{|l|}{$\begin{array}{l}\text { I try to get information on issues like the city of my university to study, } \\
\text { transportation, social life, and accommodation by using related student forums. }\end{array}$} \\
\hline \multicolumn{6}{|l|}{$\begin{array}{l}\text { I use university forums to get detailed information of the university that I plan to } \\
\text { study. }\end{array}$} \\
\hline \multicolumn{6}{|l|}{ Evaluations about the universities in student forums are important for me } \\
\hline \multicolumn{6}{|l|}{$\begin{array}{l}\text { I think the value of the university in the social media student forums affect student } \\
\text { decisions. }\end{array}$} \\
\hline Opinions shared on social media may affect students' decisions & & & & & \\
\hline
\end{tabular}

\section{$(\infty)$ EY}

This work is licensed under a Creative Commons Attribution 3.0 License. 